\title{
THE IMPACT OF SOCIAL MEDIA ON CHANGING MIND-SET OF THE YOUTH A CASE STUDY OF CHENNAI CITY
}

\author{
Dr. P.Sankar ${ }^{1} \&$ Dr.S.Chitra ${ }^{2}$
}

\begin{abstract}
Social Networking sites provide a platform for discussion on burning issues that has been overlooked in today's scenario. This research is conducted to examine the impact of social networking sites in the changing mind-set of the youth. Social media is beneficial for youth in the field of education, social media deteriorating social norms, social media is affecting negatively on study of youth. Majority of youth is shifting speedily from electronic media like as television viewers and radio listeners to the social media among all age of group. Youth rate is very much to shifting into social media so its influences are much on youth. This study also focused the influences of social media on youth and their life style, trends, educational and political awareness, physical activities, social life, their learning and so on. Youth is very important for future of any nation and country's progress and development. Now a day Social media is essential for youth in the field of education to learn new trends in education, to improve writing and communicating skills, cultural promoting, religious and political information gathering and sharing links, better living style, growth and development of society. Social media such as Facebook, WhatsApp, Skype, Twitter, YouTube and MySpace may have been freshly marketed as great leveler as gathering in which divides of races, classes, and ethnicity.

Keywords: Social media, Networking sites, WhatsApp, Facebook, Skype, Twitter, Impacts
\end{abstract}

\section{IMPACT OF SOCIAL MEDIA ON YOUTH}

Social media having various impacts on youth's life in both ends some time impacts are in the favor of youth's social life and sometimes theses impact are negative to its user. Social Media might be sometimes seemed like just a new set of cool tools for involving young people. Sometimes you may use it this way and that's ok there are some pretty cool new tools around but the emergence of social media potentially has a bigger impact than that. It impacts upon young people who are growing up in an age where media is not about broadcast content from the TV, but is about interactivity, multimedia and multi-tasking. And it impacts upon organizations who need to remain relevant to a new generation, and who find their own work and structures being changed by changing communication tools and patterns of communications (Anthony, 2009).

Social media impact on youth on both ends good and bad social media is one of most influences impacting source throughout the world including Indian people do have these influences of social media which has enhanced the exposure of the people and create more awareness among youth. Youth is highly involved in social media.

Young people are in conversation and communication with their peer groups using a wide variety of different media and media devices every day. 10 years ago, young people may have only been in touch with friends and peer-groups when hanging out at school, or meeting up in town. Now young people can be touch through instant messaging, social networks, online games and many other tools. Young people are growing up in a constantly connected society.

\section{STATEMENT OF THE PROBLEMS}

The study was design to analyzed the impact of social media on youth, how social media is influencing on youth in different aspects of social life, political awareness, religious practices, educational learning, trends adopting, sports activities and so on. This study focuses on assessing the motives of youth using social networking media analyzing the habits of colleges students in terms of the time spent for it, place and medium of accessing internet.

\section{SIGNIFICANCE OF THE STUDY}

This study is expedient to apply social media in right direction for youth and create cognizance among youth that proper use of social media become a solid tool to educate, inform and groomed the mentality level of youth social media refine their living style of public especially for youth it is also create an responsiveness that how it is effecting the social life the deteriorate social norm, society standards and ethics of society and create awareness among youth the aspect of social media.

\section{OBJECTIVES OF THE STUDY}

1. To examine the influence of social media on youth social life

\footnotetext{
${ }^{1}$ Assistant Professors, Department of Commerce, SRM University

${ }^{2}$ Assistant Professors, Department of Commerce, SRM University
} 
2. To assess direction of youth to utilizing social media.

3. To know the beneficial and preferred form of social media for youth.

4. To measure the attitude of youth towards social media and measure the spending time on social media.

5. To analyze the dependency of youth on social media and it's exhausting in life routine.

6. To recommend some measure for proper use of social media in right direction to inform and educate the people.

\section{METHODOLOGY OF THE STUDY}

The descriptive method was used to carry this study. And survey type research was conducted, through the questionnaire opinion and perception was discriminate about the impact of social media on youth and statements was developed related to the various aspect of youth's life and society. A structured questionnaire was designed to collect primary data for the study. 5.1 Study Period

The study period adopted for this work has been 3 months from Nov2015 to Jan 2016.

\subsection{Design of the Study}

The descriptive research was conducted by using the procedure survey method that is a type of methodology in social sciences studies.

\subsection{Sample}

The population of the study contains on youth of Chennai City. The researcher has confined youth as college students in Chennai city. In this research study convenient random sampling has been followed accordingly a total of 300 students have been selected as total sample size. The researcher has chosen 6 colleges for collecting primary data. From each college 50 students has been selected as respondent for this study.

\subsection{Statistical Analysis}

Statistical Package for the Social Sciences (SPSS) was used for the data analysis and interpreted. All collected data was entered at SPSS sheet to analyze the data, to separation the findings and representation the data in appropriate form, to draw the diagrams and tables.

\section{DATA ANALYSIS AND INTERPRETATION}

All gathered data entered in special packages for social sciences software and analyze in the form of table and graph and made all percentage, frequencies, mean score by applying statistical formulas.

Table 1. Favorite form of social media

\begin{tabular}{|c|c|c|c|c|c|}
\hline & Forms of Social Media & $\mathrm{F}$ & $\%$ & Valid\% & Cumulative $\%$ \\
\hline Valid & WhatsApp & 143 & 49.3 & 50.2 & 50.2 \\
\hline & Face Book & 112 & 38.6 & 39.3 & 89.5 \\
\hline & You tube & 25 & 8.6 & 8.8 & 98.2 \\
\hline & Twitter & 4 & 1.4 & 1.4 & 99.6 \\
\hline & Skype & 1 & .3 & .4 & 100.0 \\
\hline & Total & 285 & 98.3 & 100.0 & \\
\hline Missing & System & 5 & 1.7 & & \\
\hline Total & & 290 & 100.0 & & \\
\hline
\end{tabular}

Table 1 shows the statement that your favorite forms of social media $49.3 \%$ responded for whatsapp $38.6 \%$ responded for facebook $8.6 \%$ responded for youtube $1.4 \%$ responded for twitter $0.3 \%$ responded for skype.

Table 2. Social media is beneficial for youth in the field of education

\begin{tabular}{|c|c|c|c|c|c|c|}
\hline Statement & Response & $\mathrm{F}$ & $\%$ & Valid\% & Cum $\%$ & Mean \\
\hline & Strongly Disagree & 5 & 1.7 & 1.8 & 1.8 & \\
\hline & Disagree & 10 & 3.4 & 3.5 & 5.3 & \\
\hline & Uncertain & 37 & 12.8 & 13.0 & 18.3 & \\
\hline \multirow{6}{*}{$\begin{array}{l}\text { Social Medical is } \\
\text { beneficial for youth in } \\
\text { the field of education }\end{array}$} & Agree & 126 & 43.45 & 44.4 & 62.7 & \\
\hline & & & & & & 4.12 \\
\hline & Strongly Agree & 106 & 36.65 & 37.3 & 100.0 & \\
\hline & Total Response & 284 & 97.9 & 100.0 & & \\
\hline & Missing & 6 & 2.1 & & & \\
\hline & Total & 290 & 100.0 & & & \\
\hline
\end{tabular}

Table 2 shows that students were asked social media is beneficial for youth in the field of education, where $43.45 \%$ of the 
respondents agree, and $36.65 \%$ of the respondent responded strongly agree.

$>$ Students were asked if upon social media chatting, calling, sharing links, liking links is the wastage of time for youth., where $41.0 \%$ of the respondents agree, $23.8 \%$ of the respondent responded strongly agree

$>$ Students were asked if use of social media deteriorating our social norms, where $39.31 \%$ of the respondents agree, $29.31 \%$ of the respondent responded strongly agree.

$>$ Students were asked that social media is necessary for youth now a day. Where $43.80 \%$ of the respondents agree, $27.24 \%$ of the respondent responded strongly agree.

$>$ Students were asked if useless information creates ambiguity and confusion in the mind of youth. Where $42.1 \%$ of the respondents agreed, $32.07 \%$ of the respondent responded strongly agree.

Table 3. Social media is becoming a hobby of youth to kill the time

\begin{tabular}{|l|l|l|l|l|l|l|}
\hline Statement & Response & F & $\%$ & Valid\% & Cum\% & Mean \\
\hline & Strongly Disagree & 9 & 3.1 & 3.2 & 3.2 & \\
\hline & Disagree & 13 & 4.5 & 4.6 & 7.8 & \\
\hline & Uncertain & 43 & 14.8 & 15.2 & 23.0 & \\
\hline $\begin{array}{l}\text { Social Media is } \\
\text { becoming a hobby } \\
\text { of youth to kill the } \\
\text { time }\end{array}$ & Agree & 125 & 43.10 & 44.2 & 67.1 & \\
\hline & & & & & 3.99 \\
\hline & Strongly Agree & 93 & 32.07 & 32.9 & 100.0 & \\
\hline & Total Response & 283 & 97.6 & 100.0 & & \\
\hline & Missing & 7 & 2.4 & & & \\
\hline & Total & 290 & 100.0 & & & \\
\hline
\end{tabular}

Students were asked that social media is becoming a hobby of youth to kill the time. Where $43.10 \%$ of the respondents agree, $32.07 \%$ of the respondent responded strongly agree.

Table 4. Social media have positive impact on youth

\begin{tabular}{|l|l|l|l|l|l|l|}
\hline Statement & Response & F & $\%$ & Valid $\%$ & Cum\% & Mean \\
\hline & Strongly Disagree & 10 & 3.4 & 3.5 & 3.5 & \\
\hline & Disagree & 25 & 8.6 & 8.9 & 12.4 & \\
\hline & Uncertain & 74 & 25.5 & 26.2 & 38.7 & \\
\hline $\begin{array}{l}\text { Social Media have } \\
\text { positive impact on } \\
\text { youth }\end{array}$ & Agree & 110 & 37.93 & 39.0 & 77.7 & \\
\hline & & & & & & 3.68 \\
\hline & Strongly Agree & 63 & 21.72 & 22.3 & 100.0 & \\
\hline & Total Response & 282 & 97.2 & 100.0 & & \\
\hline & Missing & 8 & 2.8 & & & \\
\hline & Total & 290 & 100.0 & & & \\
\hline
\end{tabular}

Students were asked social media have positive impact on youth, where $37.93 \%$ of the respondents agree, and $21.72 \%$ of the respondent responded strongly agree.

$>$ Students were asked that social media deteriorate the social norms and ethics among youth. Where $44.83 \%$ of the respondents agree, $28.28 \%$ of the respondent responded strongly agree Students were asked that social media is playing essential role for betterment of society, where $47.24 \%$ of the respondents agree, $23.10 \%$ of the respondent responded strongly agree.

$>$ Students were asked social media is creating awareness among youth for new trends. Where $51.03 \%$ of the respondents agree, $30.00 \%$ of the respondent responded strongly agree.

$>$ Students were asked if social media is the source to get knowledge and information, where $48.62 \%$ of the respondents agree, $30.69 \%$ of the respondent responded strongly agree.

$>$ Students were asked social media are useful to connect the people all over the world. Where $46.21 \%$ of the respondents agree, $30.34 \%$ of the respondent responded strongly agree.

$>$ Students were asked that social media is essential for youth to get learning and skills. Where $51.03 \%$ of the respondents agree, $25.86 \%$ of the respondent responded strongly agree.

$>$ Students were asked if social media is playing a key role to create political awareness among youth. where $47.93 \%$ of the respondents agree, $24.48 \%$ of the respondent responded strongly agree.

$>$ Students were asked that social media is a facilitator to advertise and search business for youth. Where $40.00 \%$ of the respondents agree, $29.7 \%$ of the respondent responded strongly agree. Students were asked if social media is a latest 
form which is connecting the gender and families especially youth. Where $48.62 \%$ of the respondents agree, $20.69 \%$ of the respondent responded strongly agree.

$>$ Students were asked that social media is a great facilitator to create awareness among youth to develop global cultural. Where $50.34 \%$ of the respondents agree, $16.90 \%$ of the respondent responded strongly agree.

$>$ Students were asked that use of social media affects indirectly on play grounds and physical activities in youth. Where $26.55 \%$ of the respondent responded agree $32.07 \%$ of the respondents strongly agree.

\section{SUGGESTIONS}

$>$ After getting all findings and discussed the conclusion of collected data the researcher recommend some measures to use of social media in right direction and utilize social media favorable and appropriate manner to its users. Positive use of social media can develop the youth's academic career, their skills, better living style, to adopt new trends, fashion, and anthropology so on.

$>$ Social media is recent and most favorite form of media. it is a useful tool for youth so its use is essential to get information and knowledge when youth going to connect the social media should keep in mind that basic purpose to usage and always remember that they are going to share the information or links are not only for their gratification and interest but also for all their contacts and friends community, so be carefully utilize with social responsibility, ethically, religiously and politically appropriate links should be share.

$>$ The parent should not totally restrict but at least keep a check on the gadgets used by their children.

$>$ The student should be engaged into co-curricular activities for spending their leisure time so that student gets less spend on the internet.

$>$ The youth should motivated to stop living in a world of fake show offs created by these social networking websites.

$>$ Since the last few years, the use of social has significantly increased to make perception regarding the socio-political images. The users should be aware about the right to information which is provided to them from their respective states and societies. They should avoid from defamation and hate speech on the social media forums.

$>$ Healthy mind get progress in healthy physique. The youth should avoid from excessive use of social media. They should be balanced in their life and give proper time to the co-curricular activities in their daily life routine.

\section{CONCLUSION}

The research deals with a survey on the usage of the social media networking in the domain of youth. The social media referencing which is used in the research tool are whatsApp, Face book, Skype, YouTube, Twitter and MySpace. All the participants actively respond to this questionnaire. The return average of the questionnaire was greatly high with 97 percent. This research finds that the excessive users in the educational computer labs use the social media forms for comments, chatting, image and video sharing and texting etc. This average touches the almost half of the sampled population. This shows that they ignore their primary focus on their study and research related activities while utilizing the facility of internet in connecting with their friends on the social media networking forums with their average utilized time between 30 to 60 minutes. But the actual results may cross this maximum time period while utilizing the social media forms as 13 percent responded that they use it more than 2 hours in a single day. Their important features while using social media are SMS, video clips sharing links and comments. The users mostly face problems such as unwanted messages, unwanted friends request and controversial political links and unethical pictures and links, irrelevant religious and anti-religious messages and useless information.

The social media has impacted the youth by great force. Today they are more aware and responsible towards the things that are taking place in our nation and in the world.

Majority of the sampled population is agreed with this argument that the positive use of social media forms can brought socio-political awareness, enhance the different skills like increase language proficiency, develop online communication skills, create broader visionary power and connectivity. It is also useful for advertising, job hunting portals, publishing research articles and other techniques etc.

\section{REFERENCES}

[1] Aamoth, D. 2011, "Brief History of Skype." New York, Oxford University Press.

[2] Ahn, J. 2012, "Teenager and social network sites do of line inequalities predict their on line social networks." USA, University of Maryland.

[3] Balousha, H. 2013, "Palestian Youth on Social Media." Gaza Publications.

[4] Barneys, S. 2012, "Effects of social media on employees." New York, Tag Archive.

[5] Beattie, A. 2013, "Social media and its effects on our emotional well being." Canada, INSIGHT Planner at Metro and Freelance Film Journalist.

[6] Berkman, S. 2007, "Why youth hearts social network sites," Berkman Center for Internet and Society, Harvard University, USA.

[7] Blumler, J. G., \& Katz, E. 1974, “The uses of mass communications.” Beverly Hills, CA. Sage. 